\title{
BIRDS DISTRIBUTION IN PT EKOSISTEM KHATULISTIWA LESTARI, KUBU RAYA REGENCY, WEST KALIMANTAN PROVINCE
}

\author{
IQBAL NUR ARDIANSYAH ${ }^{1 *}$, NIRMALA AYU ARYANTI ${ }^{2)}$, DAN HARI AHMADI ${ }^{3)}$ \\ 1) Wildlife Study Group, Forestry Study Program, Faculty of Animal Husbandry, \\ Muhammadiyah University of Malang, Malang, 65152, Indonesia \\ 2) Forestry Study Program, Faculty of Animal Husbandry, Muhammadiyah University of Malang, Malang, 65152, \\ Indonesia \\ 3) PT Ekositem Khatulistiwa Lestari Menara Kuningan, Jakarta, 12940, Indonesia
}

*Email: iqbal.n.a.1995@gmail.com

Accepted 18 November 2019 / Approved 02 October 2020

\begin{abstract}
IUPHHK-RE PT Ekosistem Khatulistiwa Lestari is the habitat of various wildlife species, comprises of a restoration forest area surrounded by production forest and oil palm plantations. The threats of damages from illegal logging and land clearing activities tend to threaten the wildife existence. Therefore, this study aims to determine the distribution and diversity of bird species in PT Ekosistem Khatulistiwa Lestari. The study was conducted from January - February 2019, and data collection was conducted using the IPA (Index Ponctualle deAbondance) method. Furthermore, data analysis used diversity index, evenness index, and species similarity with dendrogram analysis using SPSS 21. The results showed that the highest bird species were found in mangroves (32 species), old swamp scrubs (26 species), young swamp scrubs (24 species), plantations (13 species), and settlement (15 species) habitats. Meanwhile, the diversity index of bird species in the five habitat types is classified as medium diversity. Species evenness with the highest value is settlement $(E=0.93)$. The dendrogram image of the settlement area showed bird species, which can be found in the other four habitats.
\end{abstract}

Keywords: diversity, bird distribution, West Borneo, dendrogram

\section{INTRODUCTION}

Birds diversity as an indicator of environmental quality, requires special attention because life is influenced by physical, chemical, and biological factors (Hidayat 2013). The widespread distribution of birds (found in almost every vegetated environment including natural and artificial ecosystems) makes birds as parts of Indonesia's biological wealth (Hadinoto et al. 2012).

According to Wisnubudi (2009), birds species distribution is strongly influenced by the suitability of bird's habitat, including environmental adaptation, competition, vegetation strata, food availability, and natural selection. However, when birds are removed from the food chain link, insects which are sources of wood will reproduce uncontrollably and become pests, which in turn will cause an imbalance in the chain of life (Wechsler and Wheeler 2012). Furthermore, plant existence is an important habitat used by birds for nesting, shelter, foraging for food, breeding, and other activities (Ridwan et al. 2015)

PT Ekosystem Khatulistiwa Lestari is one of the companies actively engaged in ecosystem restoration. To determine the success of restoration efforts, it is necessary to carry out regular monitoring for animals development and their habitat. Initial data collection was conducted in 2008 of which 26 birds species were recorded. The next data collection was conducted in 2016 and resulted in 59 being recorded. Monitoring should be regularly conducted to determine the potential of birds species usage as an indicator for the success of post-restoration area. Therefore, this study aims to determine the distribution and diversity of bird species in PT Ekosistem Khatulistiwa Lestari.

\section{RESEARCH METHODS}

This study was conducted from January to February 2019 on five types of habitats (young swamp scrubs, old swamp scrubs, plantations, mangroves, and settlements) in the IUPHHK-RE PT Ekosistem Khatulistiwa Lestari area, Kubu Raya Regency, West Kalimantan Province (Figure 1).

Data were collected along a one $\mathrm{km}$ line transect employing purposive sampling with a total of 11 transects in non-mangrove (plantations, settlements, young swamp scrubs, old swamp scrubs) and 15 transects in mangroves. The difference in the number of transects was due to the different topographic conditions and areas, thus were divided into two parts to allow higher accessibility. On each observation tract, an observation point (point count) or IPA (Induces 
Ponctuel d'Abodance) was established with an interval of 200 metres (Figure 2). Each observation point was observed for 30 minutes to record the species encountered based on the need for travel time in the field, the number of birds, and the coordinates of the birds within the observation circle diameter with a radius of 50 metres (Bibby et al. 1998). On each observation point, the environmental conditions and the vertical height of all birds directly observed were classified based on canopy strata (A: 30 metres and above, B: 20-30 metres, C: 4-20 metres, D: 1-4 metres and E: 0-1 metres). In addition, bird watching was carried out in the morning at 05:30 - 9:00 am and at 03:00 - 06:00 pm in the afternoon.

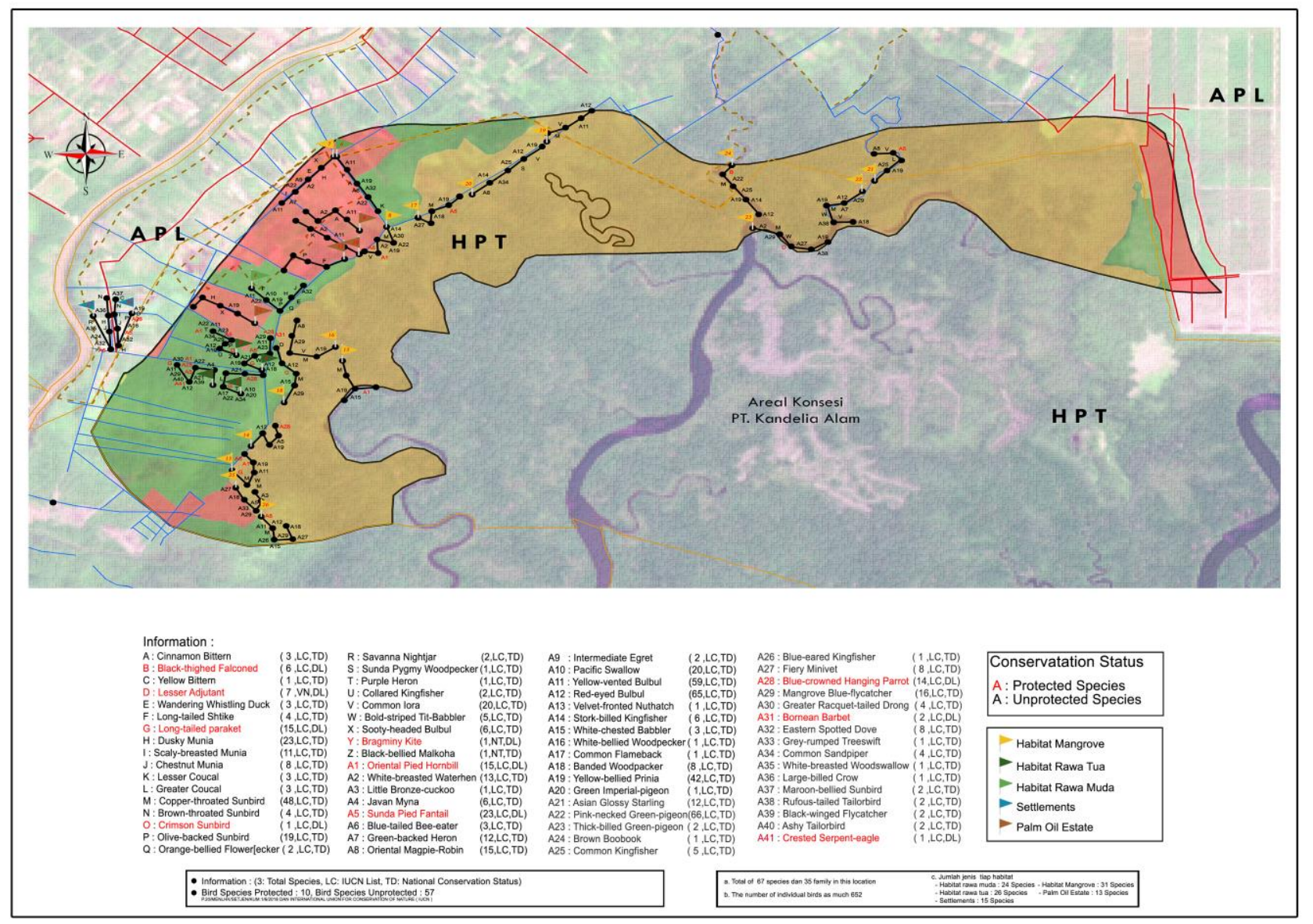

Figure 1 Map of the IUPHHK-RE PT Ekosistem Khatulistiwa Lestari research location

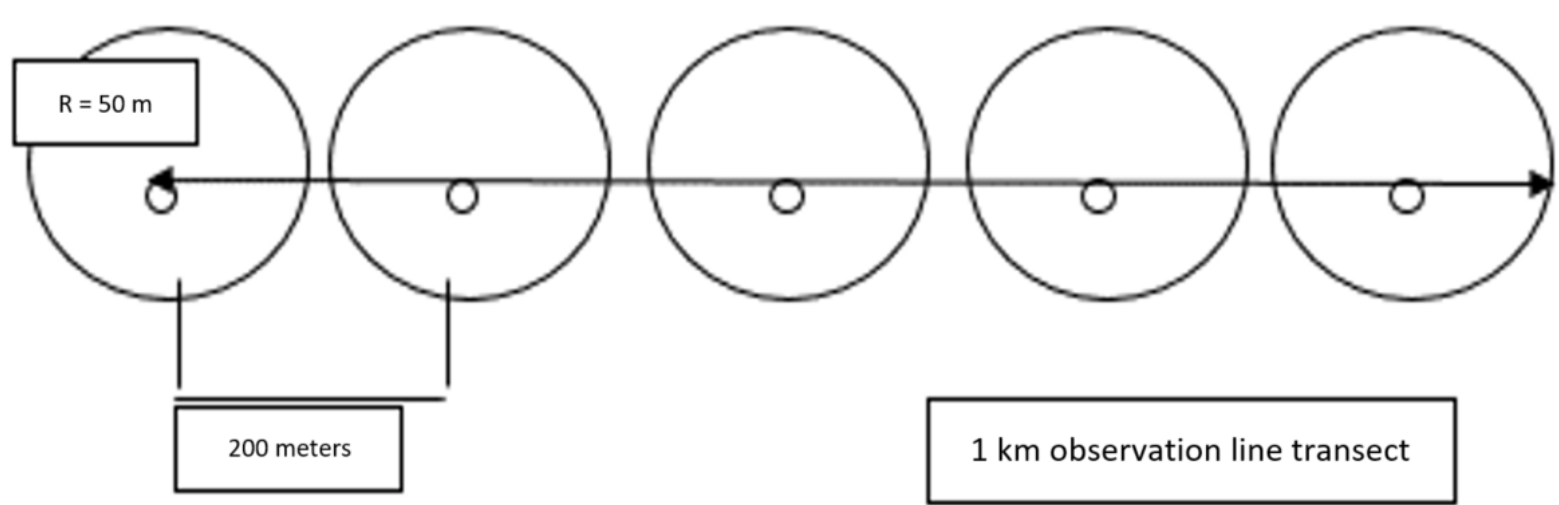

Figure 2 Point Count method with line transect used to find bird distribution data 
The distribution map of the birds was created using ArcGis, while SPSS 21 was used to process the data. Furthermore, data analysis used the following indices: Shannon-Wienner diversity index (Meffe and Carroll 1994) with the formula: $\mathrm{H}$ ' $=-\Sigma \mathrm{Pi}$ ln Pi; evenness index to determine the evenness in each community encountered and calculated using the formula: $\mathrm{E}=\mathrm{H}^{\prime} / \mathrm{ln}$ $\mathrm{S}$, where: $\mathrm{E}=$ evenness index (value between 0-10), $\mathrm{H}^{\prime}=$ bird species diversity, $\mathrm{ln}=$ natural logarithm, $\mathrm{S}=$ number of species; dominance, and species similarity in the five habitat types using SPSS 21 to produce dendrogram cluster analysis. The domination value functions was used to determine the dominant, sub-dominant, or nondominant species in an observation path. In addition, the dominance index was calculated using the following formula:

$$
\begin{gathered}
\text { Di }= \\
\text { Where : }
\end{gathered}
$$

$\mathrm{Di}=$ dominance index of a bird species

ni $=$ number of individuals from a bird species

$\mathrm{Ni}=$ number of individuals from all bird species.

The criteria for determining the domination level are as follows:

$\mathrm{Di}=0-2 \%$ is non-dominant species

$\mathrm{Di}=2-5 \%$ is sub-dominant species

$\mathrm{Di}=>5 \%$ is dominant species.

\section{RESULTS AND DISCUSSION}

\section{Distribution of Birds in IUPHHK-RE PT Ekosistem Khatulistiwa Lestari}

As many as 67 bird species of 35 families were recorded in the IUPHHK-RE of PT Ekositem Khatulistiwa Lestari, distributed among five different habitats. Some species were found within one habitat type only, such as Leptocoma calcostetha, which is found only in mangroves.

The use of bird canopy strata in the five habitat types is shown in Figure 3. Within the young swamp scrub habitats, the highest number of birds observed were found in the $\mathrm{C}$ stratum, including long-tailed shrike (Lanius schach), olive-backed sunbird (Cinnyris jugularis), orange-bellied flowerpecker (Dicaeum trigonostigma), blue-tailed bee-eater (Merops philippinus), Yellow-vented Bulbul (Pycnonotus goiavier), Common Flameback (Dinopium javanense), banded woodpecker (Chrysophlegma miniaceum), Pinknecked Green-pigeon (Treron vernans), and Bluecrowned Hanging-parrot (Loriculus galgulus). Furthermore, in old swamp scrub habitats, many birds use the C-canopy strata, such as olive-backed sunbird (Cinnyris jugularis), Collared Kingfisher (Todiramphus chloris), Black-bellied Malkoha (Rhopodytes diardi), javan myna (Acridotheres javanicus), Yellow-vented bulbul (Pycnonotus goiavier), Asian red-eyed bulbul (Pycnonotus brunneus), banded woodpecker (C. miniaceum), Asian glossy starling (Aplonis panayensis), pink-necked green pigeon (T.vernans), thick-billed green pigeon ( $T$. curvirosta), blue-crowned hanging-parrot $(L$. galgulus), and Bornean Barbet (Megalaima exima). Subsequently, in mangrove habitat, some birds are mostly found in the C-canopy strata, such as Blackthighed Falconet (Microhierax fringillarius), Copperthroated Sunbird (L. calcostetha), Olive-backed Sunbird (C. jugularis), Sunda Pygmy Woodpecker (Picoides moluccensis), Little Bronze-cuckoo (Chrysococcyx minutillus), Pied Fantail (Rhipidura javanica), yellowvented bulbul ( $P$. goiavier), Asian red-eyed bulbul ( $P$. brunneus), velvet-fronted nuthatch (Sitta frontalis), banded woodpecker (C. miniaceum), pink-necked green pigeon ( $T$. vernans), blue-crowned hanging parrot $(L$. galgulus), and mangrove blue flycatcher (Cyornis rufigrasta). In settlement habitats, birds are also mostly found in the C-canopy strata, such as brown-throated sunbird (Anthreptes malacensis), purple-throated sunbird (Leptocoma sperata), crimson sunbird (Aethopyga siparaja), olive-backed sunbird (C. jugularis), whitebreasted woodswallow (Artamus leucorynchus), whitebellied woodpecker (Dryocopus javensis), brown hawkowl (Ninox scutulata), and blue-crowned hanging-parrot (L. galgulus).

Within the mangrove forest habitat, 32 species were found belonging to 23 families (Figure 4). The Alcedinidae family is closely associated with mangrove vegetation, including stork-billed kingfisher (Pelargopsis capensis), common kingfisher (Alcedo atthis), and blue-eared kingfisher (Alcedo meninting) which used the mangrove roots just above the water surface as a place to perch and observe the fish to catch. According to Darmawan (2006), some bird species used only one or several strata since they can only occupy certain areas or because they have an equally low population. The most dominant bird species found in mangroves is the copper-throated sunbird (Leptocoma calcostetha) in the $\mathrm{C}$ and D strata. Mangrove forests have the highest bird species diversity because of the intact habitat with abundant food availability and wide area.

Young swamp scrub habitat is a natural regeneration area after forest fires. In this habitat, 24 bird species from 18 families were found, and the most dominant species was Pasific Swallow (Hirundo tahitica) which occupies the C-canopy strata with perching activity on dry twigs for resting or sunbathing.

The old swamp scrub habitat consisted of peat soil and a more complex stand composition than the young swamp scrub. The most dominant species is the Asian red-eyed bulbul (Pycnonotus brunneus), which occupies the C-canopy stratum with activities like perching or foraging on small fruits of the common fig tree (Ficus carica L). Meanwhile, the bold-striped tit-babbler (Macronus bornensis) showed preference for the deer fern (Stenochlaena palustris Burm.f.) occupying the Dcanopy stratum. 


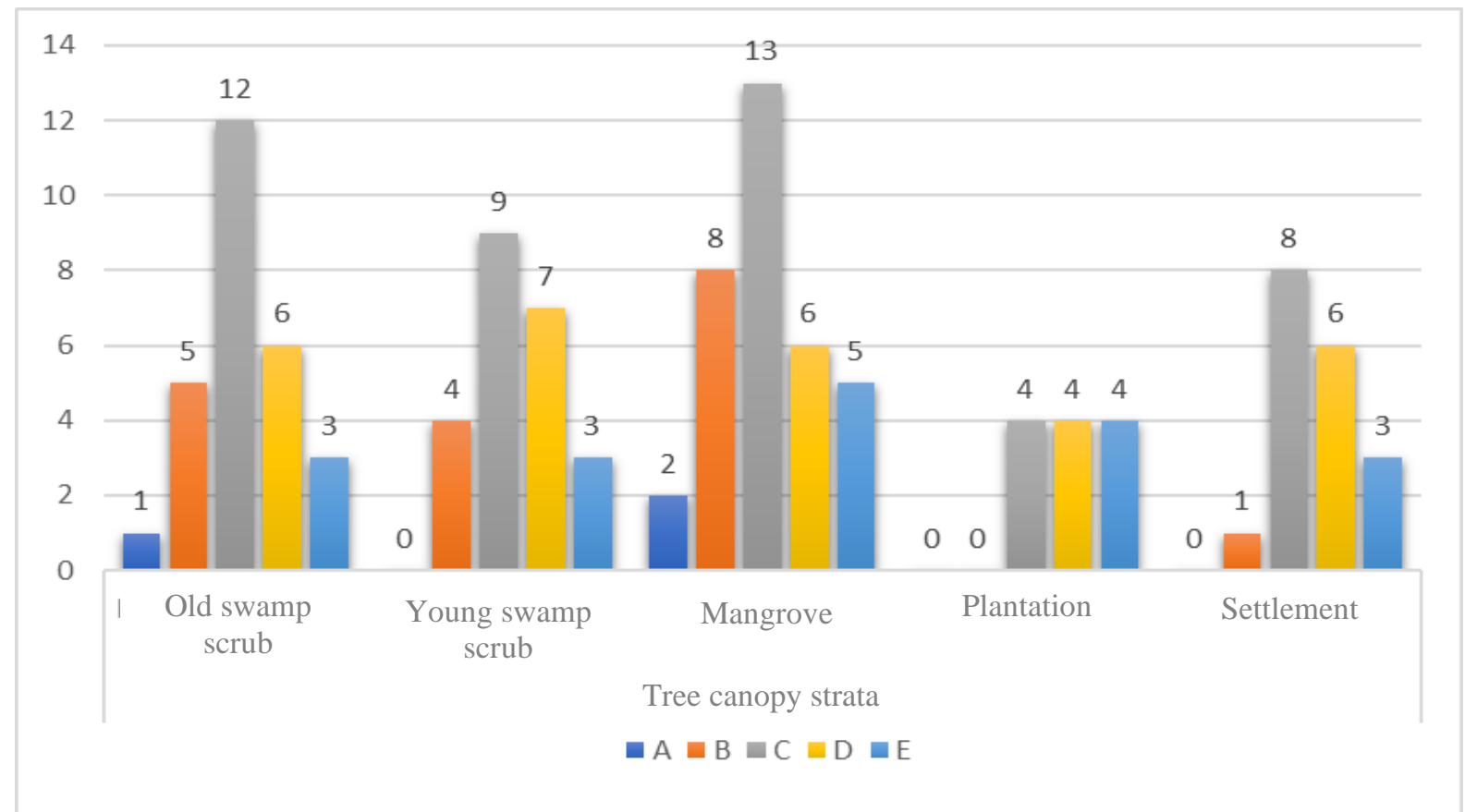

Figure 3 The use of tree canopy strata for each bird species in five habitat types in the PT Ekosistem Khatulistiwa Lestari area

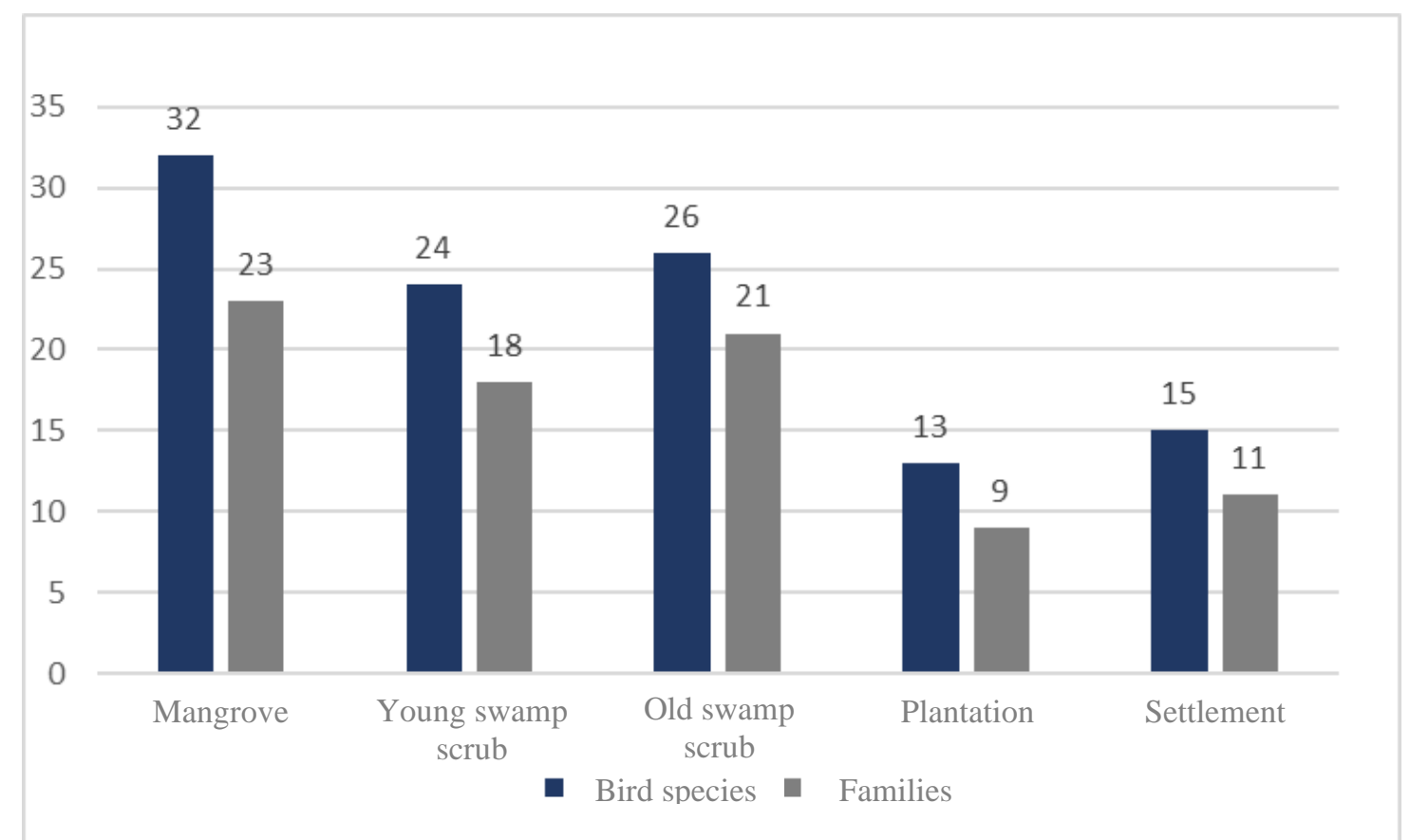

Figure 4 The encounter for the number of bird species and families in five habitat types in the PT Ekosistem Khatulistiwa Lestari area

The plantation habitat of PT Ekosistem Khatulistiwa Lestari comprised of smallholder plantations, coconut plantations (Cocos nucifera L) and oil palm plantations (Elaeis guineensis Jacq). The most dominant bird species was the pink-necked green pigeons (Treron vernans), occupying the C-canopy stratum.

In settlement areas, 15 species of 11 families were recorded. The most dominant was the olive-backed sunbird (Cinnyris jugularis) from the Nectariniidae family, which was observed using the $\mathrm{C}$ stratum and forages on $C$. nucifera coconut flower nectar. Various bird species in general, preferred the $\mathrm{C}$ stratum due to the abundance of food. 
2. Diversity, Evenness and Frequency of birds in IUPHHK-RE PT Ekosistem Khatulistiwa Lestari

PT Ekosistem Khatulistiwa Lestari area has a diversity index value within the medium category (Figure 5). The Shannon-Wiener diversity index value is classified into several categories; value of $0<\mathrm{H} '<1.5$ is categorised as having low diversity, $1.5<\mathrm{H}^{\prime}<3.5$ is moderate, and $\mathrm{H}$ '> 3.5 is high (Magurran 1988). Therefore, the bird species diversity for settlements, young swamp scrub, old swamp scrub, mangroves, and plantations indicated moderate diversities with $\mathrm{H}^{\prime}$ values of $2.5,2.75,2.7,2.8$, and 2.2 respectively. Such category suggested that PT Ekosistem Khatulistiwa Lestari still provides adequate habitat for bird cmmunities. According to Arbi (2012), the high or low diversity indices can be influenced by various factors, including the abundance of the species. The evenness index of the five habitat types indicated high similarities (Figure 5), with values for settlement ( $E=0.93)$, young swamp scrub $(\mathrm{E}=0.88)$, old swamp scrub $(\mathrm{E}=0.83)$, mangroves ( $\mathrm{E}=0.84)$, and settlements $(\mathrm{E}=0.85)$. According to Odum (1971), the evenness index value is stated to be high when it has a value $>0.60$. Also, Rahman et al. (2008) stated that the Species Evenness Index (E) value can be used as an indicator of dominance among each species within the community (Rahman et al. 2008). This value describes a community's stability in an ecosystem (Ariza et al. 2014).

Asian red-eyed bulbul (Pycnonotus brunneus) was found in two types of habitat mangroves and old swamp scrubs with a total of 65 individuals. Meanwhile, 66 pink-necked green pigeons (Treron Vernans) were found in young swamp scrubs, old swamp scrubs, mangroves, and plantations with the highest frequency of $10 \%$ (Figure 6). The four habitat types consisted of varied fruit tree species. Fruits comprised the primary diets for the pink-necked green pigeons. These birds were absent in settlement habitat since most of the plant species is coconut, and the local people collected the sap water. According to Sawitri and Garsetiasih (2015), the primary food types for pink-necked green pigeons are seeds and fruits, in addition to insects, shellfish, worms, leaves, shoots, and flowers. The birds performed activities in groups (eat, fly or perch), hence often found abundant.

This study found that the dominant species is different for each habitat type. The olive-backed sunbird (Cinnyris jugularis) is the dominant species in the settlement habitat. This habitat is dominated by coconut trees and allow the birds to forage the nectars in the coconut tree inflorescences. Pacific swallow (Hirundo tahitica) is the most dominant species found in the young swamp scrubs since this habitat is rarely overgrown by large trees and is dominated by small trees and dry branches. According to MacKinnon et al. (1998), Pacific swallows are insectivorous birds which forage while flying. Meanwhile, the old swamp scrubs is dominated by Asian red-eyed bulbul with 25 individuals. The habitat is dominated by various fruit trees that are the sources of food for this species. While in mangroves, the copperthroated sunbird is the dominating species because they forage on nectars of trees and small insects.

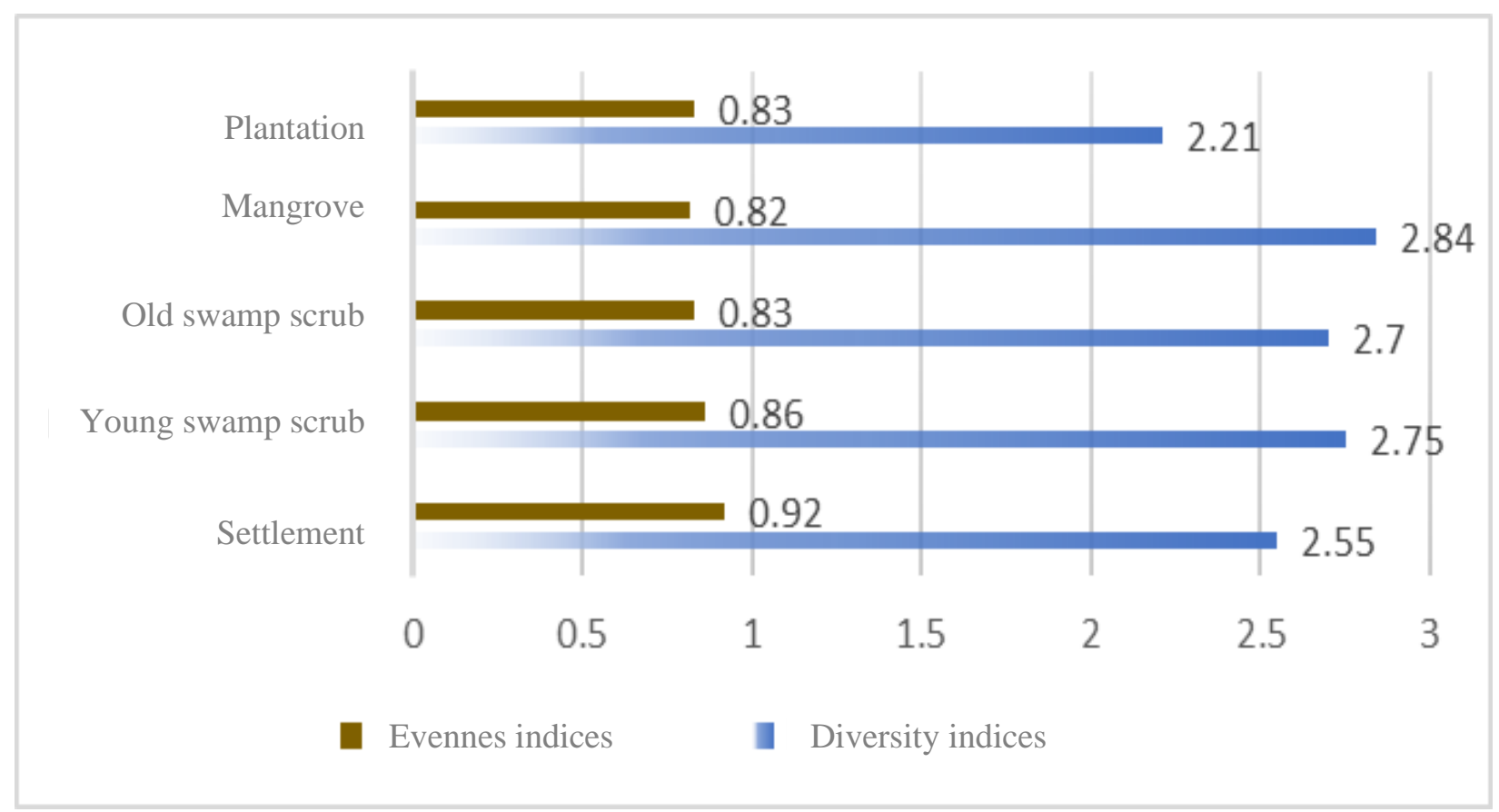

Figure 5 Evenness and diversity indices of bird species 
Furthermore, the plantation habitat is dominated by pink-necked green pigeons because they often perch in the morning on dry trees, and the presence of food abundance in the form of sengganen (Melastoma candidum D. Don) often feed by this species.

\section{Similarity of Bird Species in IUPHHK-RE PT Ekosistem Khatulistiwa Lestari}

Results of similarity analysis showed that the highest similarity index (Figure 7) was found in settlements with a value of 25 . This indicated that species found in settlements had high similarities with other vegetation types. In other words, the species at the research location can generally be found in settlement areas. Similarly, habitats having the same species were generally found in young swamp scrubs and settlements with an average value of 25 . The similarity in the two habitats was due to the similar characteristics of the study locations. Furthermore, young swamp scrubs and settlements have a fairly homogeneous vegetation composition with minimum canopy cover dominated by coconut, acacia, and oil palm plantations. The species similarity in different habitats is related to the birds' distribution which is influenced by their habitat suitability, including adaptation, vegetation, food availability, natural selection, and other natural factors (Alikodra 2002).

The differences found within the five habitat types were due to the habitat restriction of the birds, such as species that were confined in one habitat only, such as the copper-throated sunbird of the Nectariniidae family found only in mangroves. The Alcedinidae family is closely related to the presence of mangrove vegetation, including the stork-billed kingfisher (Pelargopsis capensis), common kingfisher (Alcedo atthis), and the blue-eared kingfisher (Alcedo meninting) which used mangrove roots above the water surface as a place to perch and observe the fish in the water for food. In addition, the frequency level of wild birds using plant species is one of the criteria to show their dependence level in using habitat for activities (Forestry et al. 2017).

As many as 8 species found in PT Ekosistem Khatulistiwa Lestari area are protected according to P.106/MENLHK/SETJEN/KUM.1/6/2018, namely the black-thighed falconet (Microhierax fringillarius), lesser adjutant (Leptoptilos javanicus), crimson sunbird (Aethopyga siparaja), brahminy kite (Haliastur indus), oriental pied hornbill (Anthracoceros albirostris), Malaysian pied fantail (Rhipidura javanica), bluecrowned hanging parrot (Loriculus galgalus), and crested serpent-eagle (Spilornis cheela). Furthermore, several species are protected by the IUCN, namely the lesser adjutant (Leptoptilos javanicus), long-tailed parakeet (Psitacula longicauda), black-bellied malcoha (Rhopodytes diardi), and white-chested babbler (Trichastoma rostratum). In addition, seven bird species are protected according to CITES and they are all included in the Appendix II category, that is, species not necessarily threatened with extinction, but the trade must be controlled in order to avoid utilization incompatible with their survival. These species are lesser adjutant (Leptoptilos javanicus), savanna nightjar (Camprimulgus affinis), brahminy kite (Haliastur indus), brown hawkowl (Ninox scutulata), blue-crowned hanging parrot (Loriculus galgalus), and crested serpent-eagle (Spilornis cheela) (Figure 6).

The direction for conservation measures that can be taken by PT Ekosistem Khatulistiwa Lestari using the bird distribution data (Appendix 1) is community participation-based conservation efforts, which can be packaged through bird watching as a special interest ecotourism activity. Bird watching activity among the Indonesian society began in the 1990s (Ambarwati 2011). In line with the increased community's understanding of wildlife ecological functions, their perspectives have shifted to enjoying free-live animals (not kept in cages). 
Spilornis cheela [2] Hemipus hirundinaceus

Leptocoma sperata Artamus leucorynchus Hemiprocne longipennis Megalaima exima Cyornis rufigastra [2]

Pericrocotus igneus Alcedo atthis Treron curvirosta Aplonis panayensis

Prinia flaviventris

Dinopium javanense Trichastoma rostratum [1] Sitta frontalis Pycnonotus goiavier Ardea intermedia

Butorides striata Rhipidura javanica [2]

Chrysococcyx minutillus Anthracoceros albirostris [2 3] Haliastur indus [23]

Macronous bornensis Todiramphus chloris

Picoides moluccensis Dicaeum trigonostigma Aethopyga siparaja [2] Leptocoma calcostetha Centropus bengalensis

Lonchura punctulata Psittacula longicauda [1 3]

Dendrocygna arcuata Ixobrychus sinensis Ixobrychus cinnamomeus
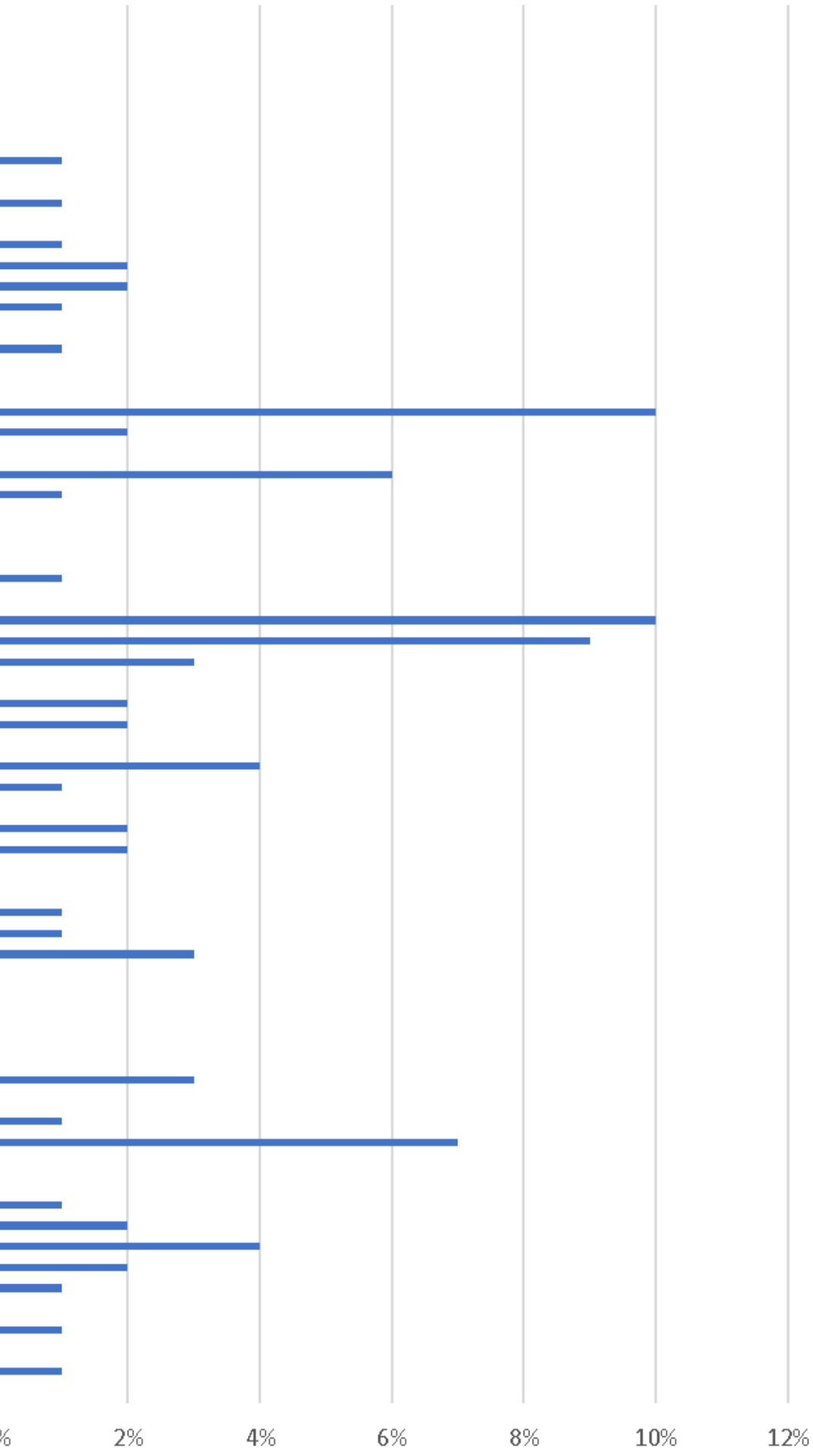

(Note: ${ }^{1}$ : IUCN; ${ }^{2}$ : P.106/MENLHK/SETJEN/KUM.1/6/2018; ${ }^{3}$ : CITES)

Figure 6 Frequency of bird species in the PT Ekosistem Khatulistiwa Lestari area 


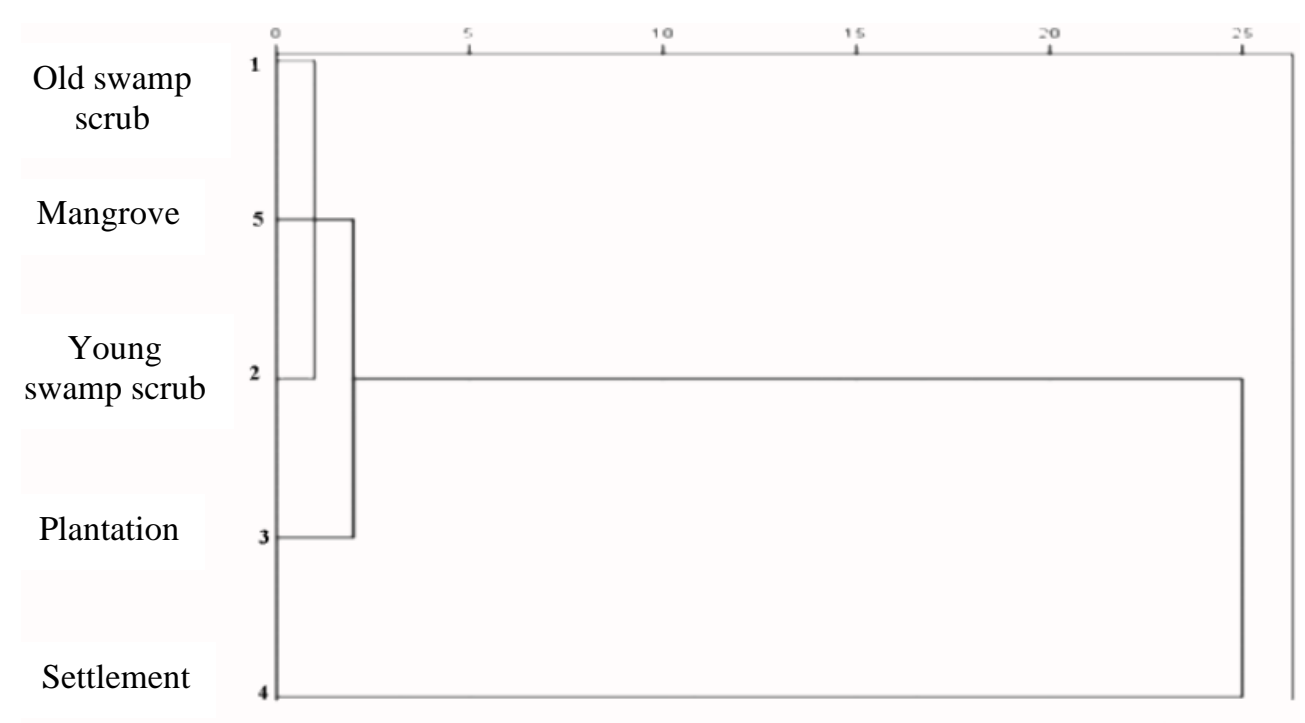

Figure 7 Dendogram of bird species similarity

Description: 1) Old swamp scrub, 2) Young swamp scrub, 3) Plantation, 4) Settlement, 5) Mangrove

\section{CONCLUSION}

There were 67 bird species of 35 families were recorded in PT Ekosistem Khatulistiwa Lestari, with the highest number of species found in mangroves (32 species) followed by old swamp scrubs (26 species), young swamp scrubs (24 species), settlements (15 species), and the least in plantation areas (13 species), and. The diversity index indicated a moderate diversity with values of the five habitats between $1.5<\mathrm{H} \quad<3.5$. Furthermore, the highest species evenness was found in settlements $(E=0.92)$ indicating the highest similarities with the other habitat types. Therefore, it can be concluded that the birds'distribution in the five habitats of PT Ekosistem Khatuliswa Lestari were evenly distributed.

\section{REFERENCES}

Alikodra HS. 2002. Pengelolaan Stawa Liar. Bogor: Pusat Antar Ilmu Hayat IPB.

Ambarwati R. 2011. Potensi Kebun Binatang Surabaya sebagai tempat pembelajaran konservasi burung. Prosiding Seminar Nasional Sains 2011. Semarang: Program Pascasarjana Unesa.

Arbi UY. 2012. Komunitas moluska di padang lamun Pantai Wori, Sulawesi Utara. Jurnal Bumi Lestari. 12(1): 55-65.

Ariza YS, Dewi BS, Darmawan A. 2014. Keanekaragaman jenis amfibi (Ordo Anura) pada beberapa tipe habitat di Youth Camp Desa Hurun Kecamatan Padang Cermin Kabupaten Pesawaran. Jurnal Sylva Lestari. 2(1): 21-30.
Bibby C, Jones M, Marsden, S. 1998. expedition field techniques: Bird surveys. London: Royal Geographic Society.

Darmawan MP. 2006. Keanekaragaman jenis burung pada beberapa tipe habitat di Hutan Lindung Gunung Lumut Kalimantan Timur [skripsi]. Bogor: Institut Pertanian Bogor.

Hadinoto, Mulyadi A, Siregar YI. 2012. Keanekaragaman jenis burung di Hutan Kota Pekanbaru. Jurnal Ilmu Lingkungan. 6(1) : 25-42.

Hidayat O. 2013. Keanekaragaman spesies avifauna di KHDTK Hambala, Nusa Tenggara Timur. Jurnal Penelitian Wallacea. 2(1): 12-25.

MacKinnon J, Phillipps K, van Balen B. 1998. A field guide of the birds of Borneo, Sumatra, Java and Bali. Bogor: Puslitbang Biologi LIPI - Birdlife International Indonesia Program.

Magurran AE. 1988. Ecology Diversity and Its Measurement. New Jersey: Princenton University Press.

Meffe GK, Carroll CR. 1994. Principles of Conservation Biology. Massachussets: Sinauer Association INC.

Odum EP. 1971. Fundamentals of Ecology. Third Edition. Philadelphia: W. B. Sounder Co.

Rahman DA, Ramadhan EP, Santosa Y. 2018. Studi keanekaragaman mamalia pada beberapa tipe habitat di Stasiun Penelitian Pondok Ambung Taman Nasional Tanjung Puting Kalimantan Tengah. Media Konservasi. 13(3): 1-7.

Ridwan M, Choirunnafi A, Sugiyarto, Suseno WA, Putri RDA. 2015. Hubungan keanekaragaman burung dan komposisi pohon di Kampus Kentingan Universitas Sebelas Maret Surakarta, Jawa Tengah. Proseding Seminar Nasional Masyarakat Biodiversity Indonesia. 1(3): 660-666. 
Sawitri R, Garsetiasih R. 2015. Habitat dan populasi punai (Columbidae) di Mempawah dan Suaka Margasatwa Pelaihari. Penelitian Hutan dan Konservasi Alam. 209-221.
Wechsler D, Wheeler BK. 2012. BirdCast: Why You Should Care: Birds as Bioindicators. http://www.birdsource.org.

Wisnubudi G. 2009. Penggunaan strata vegetasi oleh burung di Kawasan Wisata Taman Nasional Gunung Halimun-Salak. Jurnal Vis Vitalis. 2(2) : 41-49.

Appendix 1. Bird species encounters per habitat type

\begin{tabular}{|c|c|c|c|c|c|c|}
\hline \multirow[b]{2}{*}{ No. } & \multirow[b]{2}{*}{ Bird species } & \multicolumn{5}{|c|}{ Checklist of bird species per land use } \\
\hline & & Settlement & $\begin{array}{l}\text { Young swamp } \\
\text { scrub }\end{array}$ & $\begin{array}{l}\text { Old swamp } \\
\text { scrub }\end{array}$ & Mangrove & Plantation \\
\hline 1 & Ixobrychus cinnanomeus & & $\sqrt{ }$ & & & $\sqrt{ }$ \\
\hline 2 & Microhierax fringillarius & & $\sqrt{ }$ & & $\sqrt{ }$ & \\
\hline 3 & Ixobrychus sinensis & $\sqrt{ }$ & & & & \\
\hline 4 & Leptoptilos javanicus & & & $\sqrt{ }$ & $\sqrt{ }$ & \\
\hline 5 & Dendrocygna arcuata & & $\sqrt{ }$ & & & $\sqrt{ }$ \\
\hline 6 & Lanius schach & & $\sqrt{ }$ & & & \\
\hline 7 & Psitacula longicauda & & $\sqrt{ }$ & $\sqrt{ }$ & $\sqrt{ }$ & \\
\hline 8 & Lonchura fuscans & $\sqrt{ }$ & $\sqrt{ }$ & & & $\sqrt{ }$ \\
\hline 9 & Lonchura punctulata & $\sqrt{ }$ & & & & $\sqrt{ }$ \\
\hline 10 & Lonchura atricapilla & $\sqrt{ }$ & $\sqrt{ }$ & & & \\
\hline 11 & Centropus bengalensis & & $\sqrt{ }$ & & & $\sqrt{ }$ \\
\hline 12 & Centropus sinensis & & $\sqrt{ }$ & & $\sqrt{ }$ & \\
\hline 13 & Leptocoma calcostetha & & & & $\sqrt{ }$ & \\
\hline 14 & Anthreptes malacensis & $\sqrt{ }$ & & & & \\
\hline 15 & Aethopyga siparaja & $\sqrt{ }$ & & & & \\
\hline 16 & Cinnyris jugularis & $\sqrt{ }$ & $\sqrt{ }$ & $\sqrt{ }$ & $\sqrt{ }$ & $\sqrt{ }$ \\
\hline 17 & Dicaeum trigonostigma & & $\sqrt{ }$ & & & \\
\hline 18 & Caprimulgus affinis & $\sqrt{ }$ & & & & \\
\hline 19 & Picoides moluccensis & & & & $\sqrt{ }$ & \\
\hline 20 & Lacedo pulchella & & & $\sqrt{ }$ & & \\
\hline 21 & Todiramphus chloris & & & $\sqrt{ }$ & & \\
\hline 22 & Aegithina tiphia & & & & $\sqrt{ }$ & \\
\hline 23 & Macronus bornensis & & & $\sqrt{ }$ & $\sqrt{ }$ & \\
\hline 24 & Pycnonotus aurigaster & & & & & $\sqrt{ }$ \\
\hline 25 & Haliastur indus & & & & & $\sqrt{ }$ \\
\hline 26 & Rhopodytes diardi & & & $\sqrt{ }$ & & \\
\hline 27 & Anthracoceros albirostris & & & $\sqrt{ }$ & $\sqrt{ }$ & \\
\hline 28 & Amaurornis phoenicurus & & & $\sqrt{ }$ & $\sqrt{ }$ & $\sqrt{ }$ \\
\hline 29 & Chrysococcyx minutillus & & & & $\sqrt{ }$ & \\
\hline 30 & Acridotheres javanicus & & & $\sqrt{ }$ & & \\
\hline 31 & Rhipidura javanica & $\sqrt{ }$ & & $\sqrt{ }$ & $\sqrt{ }$ & \\
\hline 32 & Merops philippinus & & $\sqrt{ }$ & & & \\
\hline 33 & Butorides striata & & & & $\sqrt{ }$ & $\sqrt{ }$ \\
\hline
\end{tabular}




\begin{tabular}{|c|c|c|c|c|c|c|}
\hline \multirow[b]{2}{*}{ No. } & \multirow[b]{2}{*}{ Bird species } & \multicolumn{5}{|c|}{ Checklist of bird species per land use } \\
\hline & & Settlement & $\begin{array}{l}\text { Young swamp } \\
\text { scrub }\end{array}$ & $\begin{array}{l}\text { Old swamp } \\
\text { scrub }\end{array}$ & Mangrove & Plantation \\
\hline 34 & Copsychus saularis & & & & $\sqrt{ }$ & \\
\hline 35 & Ardea intermedia & & $\sqrt{ }$ & & & \\
\hline 36 & Hirundo tahitica & & $\sqrt{ }$ & & & \\
\hline 37 & Pycnonotus goiavier & & $\sqrt{ }$ & $\sqrt{ }$ & $\sqrt{ }$ & $\sqrt{ }$ \\
\hline 38 & Pycnonotus brunneus & & & $\sqrt{ }$ & $\sqrt{ }$ & \\
\hline 39 & Sitta frontalis & & & & $\sqrt{ }$ & \\
\hline 40 & Pelargopsis capensis & & & & $\sqrt{ }$ & \\
\hline 41 & Trichastoma rostratum & & & & $\sqrt{ }$ & \\
\hline 42 & Dryocopus javensis & $\sqrt{ }$ & & & & \\
\hline 43 & Dinopium javanese & & $\sqrt{ }$ & & & \\
\hline 44 & Chrysophlegma miniaceum & & $\sqrt{ }$ & $\sqrt{ }$ & $\sqrt{ }$ & \\
\hline 45 & Prinia plaviventris & $\sqrt{ }$ & $\sqrt{ }$ & $\sqrt{ }$ & $\sqrt{ }$ & $\sqrt{ }$ \\
\hline 46 & Ducula aenea & & $\sqrt{ }$ & & & \\
\hline 47 & Aplonis panayensis & & $\sqrt{ }$ & $\sqrt{ }$ & & \\
\hline 48 & Treron vernans & & $\sqrt{ }$ & $\sqrt{ }$ & $\sqrt{ }$ & $\sqrt{ }$ \\
\hline 49 & Treron curvirosta & & & $\sqrt{ }$ & & \\
\hline 50 & Ninox scutulata & $\sqrt{ }$ & & & & \\
\hline 51 & Alcedo atthis & & & & $\sqrt{ }$ & \\
\hline 52 & Alcedo meninting & & & & $\sqrt{ }$ & \\
\hline 53 & Pericrocotus igneus & & & & $\sqrt{ }$ & \\
\hline 54 & Loriculus galgulus & $\sqrt{ }$ & $\sqrt{ }$ & $\sqrt{ }$ & $\sqrt{ }$ & \\
\hline 55 & Cyornis rufigrasta & & & $\sqrt{ }$ & $\sqrt{ }$ & \\
\hline 56 & Dicrucus paradiseus & & & $\sqrt{ }$ & $\sqrt{ }$ & \\
\hline 57 & Megalaima exima & & & $\sqrt{ }$ & & \\
\hline 58 & Streptopelia chinensis & $\sqrt{ }$ & $\sqrt{ }$ & & & \\
\hline 59 & Hemiprocne longipennis & & & & $\sqrt{ }$ & \\
\hline 60 & Actitis hypoleucos & & $\sqrt{ }$ & $\sqrt{ }$ & $\sqrt{ }$ & \\
\hline 61 & Artamus leucorynchus & $\sqrt{ }$ & & & & \\
\hline 62 & Corvus macrorhynchos & $\sqrt{ }$ & & & & \\
\hline 63 & Leptocoma sperata & & & & & $\sqrt{ }$ \\
\hline 64 & Orthotomus sericeus & & & & $\sqrt{ }$ & \\
\hline 65 & Hemipus hirundinaceus & & & $\sqrt{ }$ & & \\
\hline 66 & Orthotomus ruficeps & & & $\sqrt{ }$ & & \\
\hline 67 & Spilornis cheela & & & $\sqrt{ }$ & & \\
\hline
\end{tabular}

